\title{
Paronychia Argentea: A Critical Comprehensive Review on its Diverse Medicinal Potential and Future as Therapeutics
}

\author{
Vishnu Priya Veeraraghavan ${ }^{1, *}$, Sardar Hussain², Janardhana Papayya Balakrishna ${ }^{3}$, Surapaneni Krishna \\ Mohan $^{4}$
}

Vishnu Priya Veeraraghavan ${ }^{1, *}$, Sardar Hussain², Janardhana

Papayya Balakrishna ${ }^{3}$,

Surapaneni Krishna Mohan ${ }^{4}$

'Department of Biochemistry, Saveetha Dental College \& Hospital, Saveetha Institute of Medical \& Technical Sciences (SIMATS)

Saveetha University, Velappanchavadi.

Chennai - 600 077, Tamil Nadu, INDIA.

${ }^{2}$ Department of Biotechnology, Government

Science College, Chitradurga-577501,

Karnataka, India

${ }^{3}$ Department of Stem Cell Biology, Stellixir Biotech Pvt Ltd, No.V-31, 2nd floor, 10th Main Road, Peenya 2nd Stage Industrial Area, Bangalore - 560058, Karnataka, INDIA. ${ }^{4}$ Department of Biochemistry, Panimalar Medical College Hospital \& Research Institute Varadharajapuram, Poonamallee, Chennai600 123, Tamil Nadu, INDIA.

\section{Correspondence}

Vishnu Priya Veeraraghavan., PhD

Department of Biochemistry, Saveetha Dental College \& Hospital, Saveetha Institute of Medical \& Technical

Sciences (SIMATS), Saveetha University, Velappanchavadi, Chennai - 600 077, Tamil Nadu, INDIA

E-mail: drvishnupriyav@gmail.com

History

- Submission Date: 13-04-2020;

- Review completed: 27-04-2020;

- Accepted Date: 03-06-2020

DOI : 10.5530/pj.2020.12.165

Article Available online http://www.phcogj.com/v12/i5

\section{Copyright}

(c) 2020 Phcogj.Com. This is an open access article distributed under the terms of the Creative Commons Attribution 4.0 International license.

\section{ABSTRACT}

Background: Paronychia argentea has been used since long as a traditional medicine for the treatment of diabetes, kidney stones, anti-microbial and many other human diseases. However, the plant has not been explored much. In the present scenario of drug resistance and toxicity associated with available drugs, there is a need for elaborated studies of plants like Paronychia argeneta which had been used as folk medicines. Aim and Objectives: The present article is focused on reviewing the ethnopharmacology, phytochemistry, traditional usage, biological activities, of Paronychia argentea which has been used in traditional medicinal system for ages. The aim of the study was to assess the ethnopharmacological usage of this plant and to explore therapeutic potentials and future opportunities for research. Materials and Methods: Information on the traditional usage and studies of the Paronychia argentea was gathered from from various journals, MSc dissertation, conference abstract, local books. Various search engines including Google Scholar, Baidu Scholar, Elsevier, ACS, Pubmed, Web of Science, CNKI and EMBASE were used to collect the information along with libraries. Results: Paronychia argentea has played an important role in traditional medicines in Algeria, Portugal, Israel and Jordan. The aerial parts of this plant are used as diuretics in Algerian traditional medicines and are used as antiurolithiasis. Leaf decoction of this plant is also used as diuretic. Paronychia argentea has been used as analgesic, treatment of stomach ulcer, anorexia, and flatulence in Portugal. Scientific studies on extracts of Paronychia revealed a wide range of pharmacological activities including anti-microbial activity, anti-oxidant, nephroprotective activity. Moreover, few reports have given contradictory data for usage of Paronychia when compared with its traditional usage. As in the case of alpha-amylase inhibitory efficacy of PA, it was observed that PA inhibits alpha-amylase activity but later on it was proven that PA does not have a hypoglycemic effect. Main bioactive metabolites present in this plant include alkaloids, flavonoids, volatile oils, etc. Conclusions: Based on this review, there are evidences from various studies regarding pharmacological effects of this plant as nephroprotective, anti-oxidant, anti-microbial activity. Some indications from in vitro studies have confirmed the inhibitory activity of this plant extract against alpha amylase enzyme. The available literature showed that most of the activities of the Paronychia can be accredited to the flavonoids present in them. Data regarding mechanisms of action of this plant along with pharmacokinetics, toxicology studies is still limited, which indicate the need of such studies for the clinical usage of this plant.

Key words: Paronychia argentea, Nephroprotective, Anti-microbial, Anti-oxidant, Ulcerative colitis, Bioactivity, Oxidative stress, Herbal medicine, Therapeutic value.

\section{INTRODUCTION}

Herbal medicines have been used in almost all the countries, since the beginning of history. A vast repository of such plants with medicinal values has not been explored much. There is need to establish a common platform which has the information regarding traditional original usage and local names of such plant along with other therapeutic efficacies of such plants. It is very unfortunate that in the current technology world, this area has not been explored much. However, renewed interest in this area has arisen, due to emerging problem of drug resistance and toxicity associated with available drugs. One such plant with potential therapeutic value is Paronychia argentea.

\section{Botanical classification and habitat}

Paronychia argentea (PA) was first described by Jean-Baptiste Lamarck. ${ }^{1}$ Its taxonomy is as follows:

Superdivision:Spermatophyta

Division:Angiospermae

Class:Dicotyledoneae

Family:Caryophyllaceae

Genus:Paronychia

PA is a Perennial plant with stems spreading on the ground. It is in leaf all year and flowers appear from July to August. Flowers of this plant are small and arranged in heads surrounded by hyaline bracts. It is a hermaphrodite species and pollination occurs by

Cite this article: Veeraraghavan VP, Hussain S, Balakrishna JP, Mohan SK. Paronychia Argentea: 
insects. Plant grows well in sandy and loamy soils. PA cannot grow in the shade, since it requires complete exposure to sun. The main habitat of plant includes all the area around the Mediterranean Sea. It grows in abandoned or dry terrains, waste ground, dunes and ditches and flourishes from winter to summer. It has been reported in waste places of mountains; Irbid, Ajloun, Jarash, Amman, Karak, Tafila and Mafraq. Abusaief et al. ${ }^{2}$ have recorded the presence of PA Lam. species at $\mathrm{Al}$ Mansora in Al-Jabal Al-Akhdar-Libya. It has also been reported in Califorina, ${ }^{3}$ at Akhanasira range reserve of Jordan, ${ }^{4}$ inSpain. ${ }^{5}$

\section{Traditonal medicinal value}

PA is the most common plant used abundantly in conventional medicines in Algeria and is popularly known as Arabic tea (Kassaretlahdjer, Fettatetlahdjer or Bissatelmoulouk). PA have high content of flavonoids isorhamnetin, quercetin and luteolin. ${ }^{6}$ The aerial parts of this plant are used in as diuretic in Algerian traditional medicines. It is also used for curing renal diseases, especially as antiurolithiasis. ${ }^{7}$ It has been reported that PA also has digestive, ${ }^{8}$ hypoglycemic, ${ }^{9}$ and antimicrobial activity. ${ }^{10}$ Diuretic potential of PA has been described by Dafni et al. ${ }^{11}$ along with its usage to treat kidney stones, diabetes and cardiovascular diseases. It was also used as a blood purifier. ${ }^{12}$ In Portugal, PA has been used as analgesic, treatment of stomach ulcer, anorexia and flatulence. ${ }^{13}$ Decoction of aerial parts of PA is being used in Jordan as traditional medicine known as 'rejel el-hamama'or 'shoishet el-raei'for UTI infections and other diseases ${ }^{14}$ Lev. ${ }^{15}$ The tisane of its leaves is used for treating diabetes in Israel. ${ }^{16,17}$

\section{HPLC analysis of Paronychia argentea}

A study based on High pressure liquid chromatography (HPLC) method of analysis was planned to determine the two major constituents of Paronychia argentea dry extract (PAE) (Figure 1). This was based on establishing a chromatographic method to analyse, determine and standardize the two main chemical constituents in PAE viz., vanillic acid and luteolin (Table 1). It was observed that luteolin and vanillic acid were completely separated from other components in the PAE with an Rf value of 1.3 and $5.7 \mathrm{~min}$. respectively. Two separate peaks of both these compounds were concurrently separated and were determined from other components in PAE collected from the plants present in Jordan area. The concentration of Luteolin was found to be $0.4 \%$ and that of vanillic acid to be $0.1 \%$ using a validated chromatographic method of analysis. ${ }^{18}$ Another detailed study was carried out to do the phytochemical characterization of PA collected from the region of Adekar (West of Bejaia, Algeria). The main aim of this study was to characterize the flavonoid profile of PA along with evaluation of antioxidant property of the ethanolic extract, decoction and infusion of PA aerial parts. HPLC along with diode array detection and electrospray ionization mass spectrometry was used to analyze the flavonoid contents in PA (Figure 2). In order to identify and estimate the antioxidant property of the plant extracts, four methods were used. These included evaluations of the reducing power along with<smiles>COc1cc(C(=O)O)ccc1O</smiles>

Vanillic acid<smiles>O=c1cc(-c2ccc(O)c(O)c2)oc2cc(O)cc(O)c12</smiles>

luteolin
Figure 1: Chemicals derived from Paronychia argenteaby High pressure liquid chromatography (HPLC).

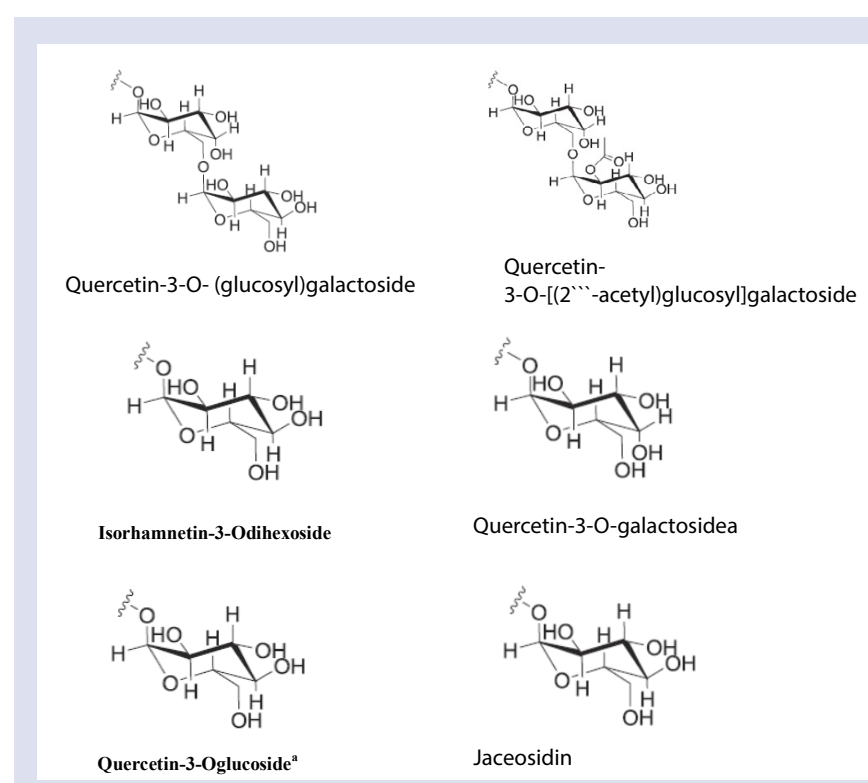

Figure 2: Flavonoids contents in Paronychia argentea by HPLC-UV/DAD and HPLC-ESI-MS"

estimation of lipid peroxidation inhibition and scavenging of free radicals like DPPH• and NO•. Results showed eleven compounds of which six were characterized for the first time. The six new compounds isolated were isorhamnetin-3-O-dihexoside, quercetin-3-O-glucoside, quercetinmethylether-O-hexoside, quercetin, jaceosidin and isorhamnetin. It was found that highest flavonoid content was present in the ethanolic extract followed by decoction and infusion respectively. Protocol standardized by Hseu et al. ${ }^{19}$ was used to evaluate the reducing power of extracts. DPPH• free radical scavenging activity was determined using protocol by Suja et al. ${ }^{20}$ and to evaluate the inhibition of lipid peroxidation activity, method by Chan et al. ${ }^{21}$ was used. It was found that best antioxidant activity was shown by decoction for all the four assays. The data strengthened the antioxidant potential of PA for therapeutic usage. ${ }^{22}$ Another study identified two new oleanane saponins and one new flavonol glycoside along with 6 flavonoids which have been identified in aerial parts of PA previously also. The structure of the compounds was elucidated using $1 \mathrm{D}$ and $2 \mathrm{D} \mathrm{NMR} .{ }^{23}$ The various classes of phytochemicals present in the Paronychia argentea were shown in Table 2.

\section{Bioactivity}

PA possesses potential therapeutic properties such as anti-inflammatory, antidiabetic, nephroprotective etc. This section focuses in detail on its various medicinal properties along with the shortcomings of the studies because of which this plant has not reached much up to clinical trials and clinics.

\section{Nephroprotective}

Urinary stone is one of the most common disorder and percentage reappearance of these stones is very high in male followed by female. ${ }^{24}$ The main constituent analyzed in these stones is Calcium oxalate $(80 \%) .{ }^{25}$ Formation of a kidney stone is a complex process involving various physiochemical events in succession. ${ }^{26,27}$ Standard treatment regimen for eliminating kidney stones includes extracorporeal shockwave lithotripsy (ESWL) and drug treatment. However, ESWL is related to severe side effects including traumatic effects of shock waves, persistence of residual stone fragments, infection. It may also cause renal injury, effect the functions of kidney, haemorrhage and hypertension. ${ }^{28,29}$ These side effects emphasize the need of alternative medicinal approaches, of which medicinal plants may be the safest. 
Table 1: Compounds identified in Paronychia argéntea.

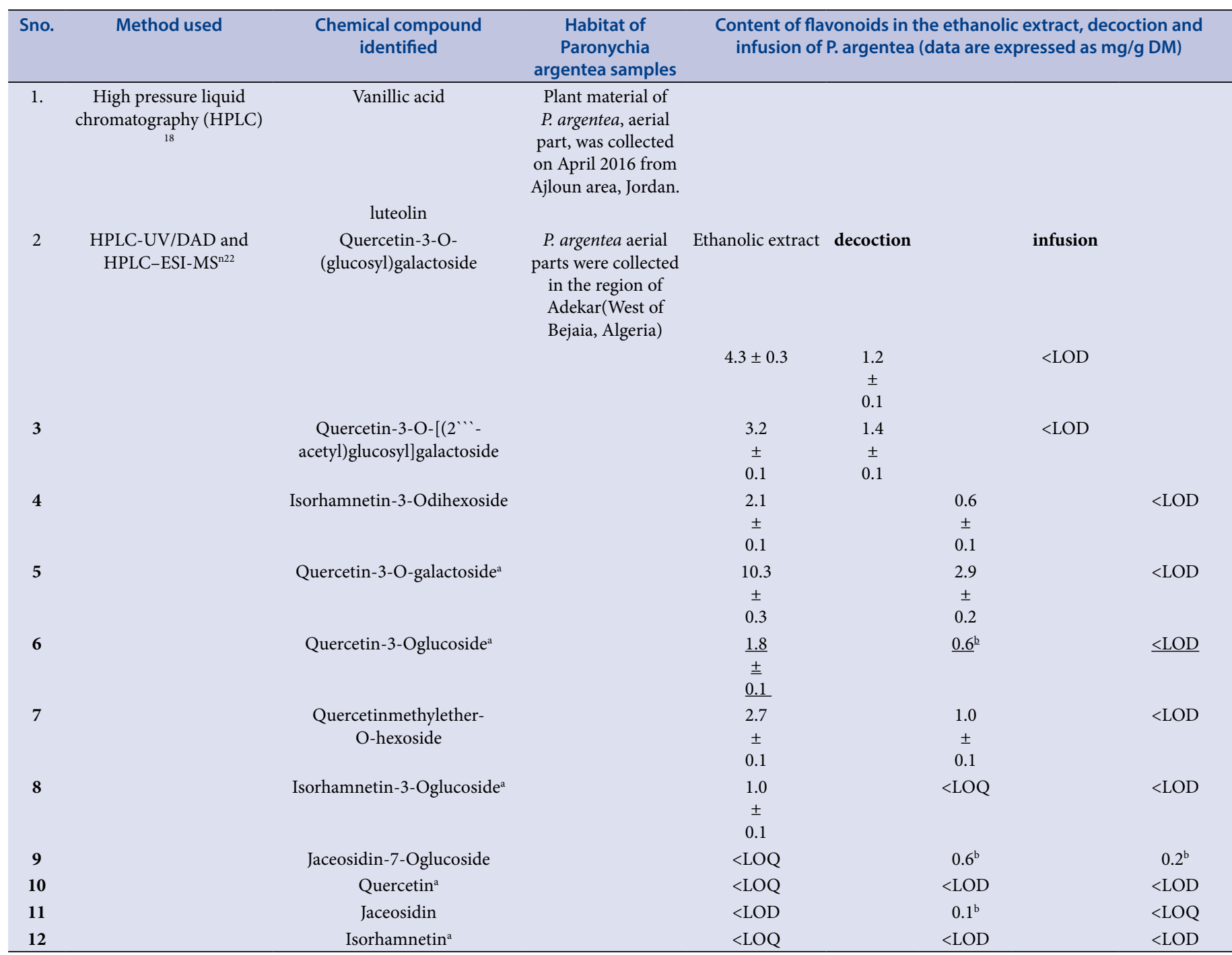

Abbreviation:limit of detection (LOD) and thelimit of quantification (LOQ)

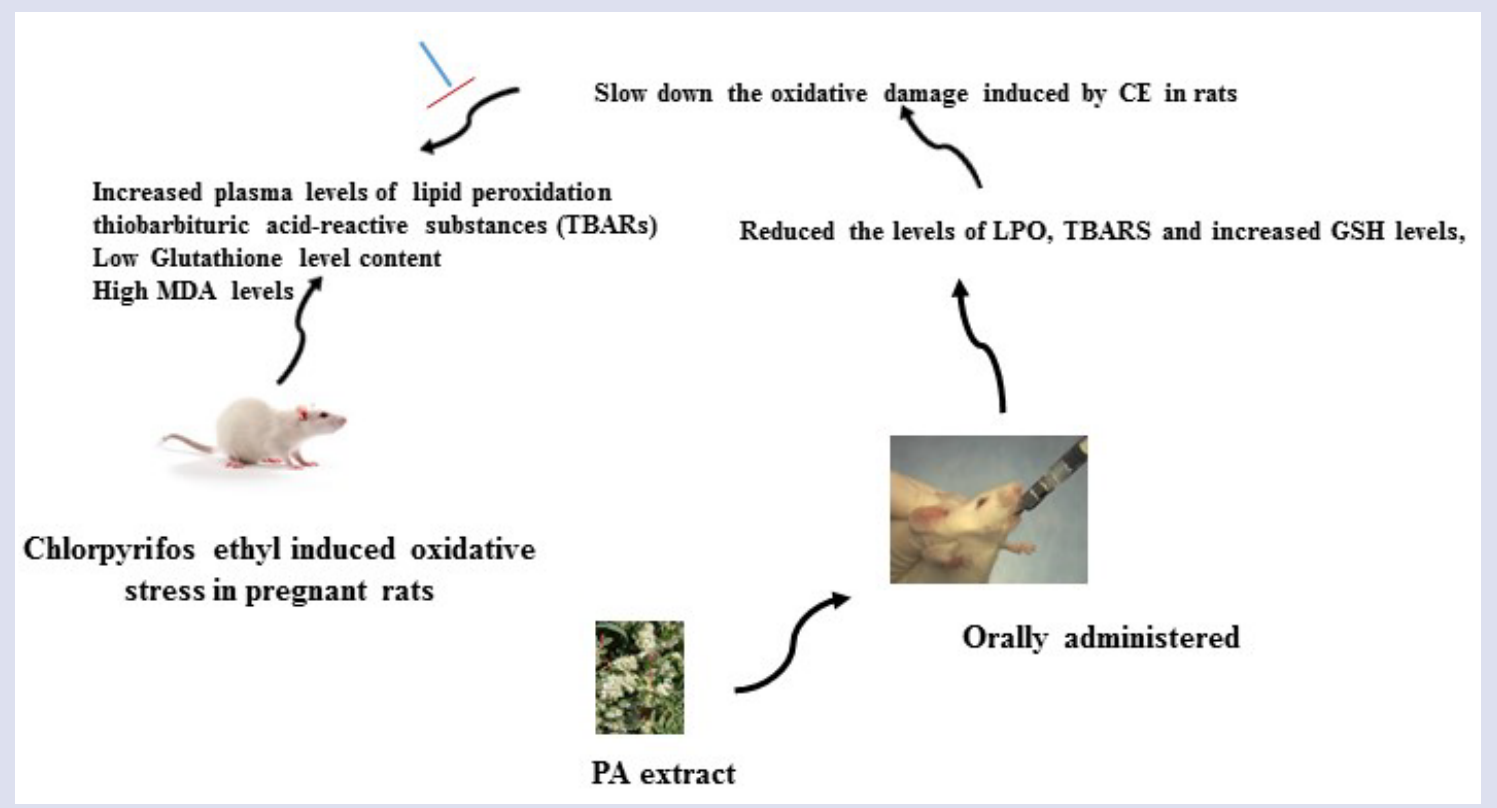

Figure 3: Mechanism of anti-oxidant potential of PA. 
Table 2: Classes of phytochemicals present in the Paronychia argéntea.

\begin{tabular}{|c|c|c|}
\hline Classes of Phytochemicals & Solvent & - = absence; $+=$ presence $;++=$ abundant \\
\hline \multirow{3}{*}{ Sterols and Terpenoids } & $\mathrm{CHCl}_{3}$ & +++ \\
\hline & $\mathrm{EtOH}$ & Nil \\
\hline & $\mathrm{H}_{2} \mathrm{O}$ & \\
\hline \multirow{3}{*}{ Flavonoids } & $\mathrm{CHCl}_{3}$ & Nil \\
\hline & $\mathrm{EtOH}$ & ++ \\
\hline & $\mathrm{H}_{2} \mathrm{O}$ & \\
\hline Phenolics & $\begin{array}{l}\mathrm{CHCl}_{3} \\
\mathrm{EtOH}\end{array}$ & ++ \\
\hline \multirow{3}{*}{ Tannins } & $\begin{array}{c}\mathrm{H}_{2} \mathrm{O} \\
\mathrm{CHCl}_{3}\end{array}$ & \\
\hline & $\mathrm{EtOH}$ & +++ \\
\hline & $\mathrm{H}_{2} \mathrm{O}$ & \\
\hline \multirow[t]{2}{*}{ Saponins } & $\begin{array}{l}\mathrm{CHCl}_{3} \\
\mathrm{EtOH}\end{array}$ & +++ \\
\hline & $\mathrm{H}_{2} \mathrm{O}$ & \\
\hline Reducing compounds & $\begin{array}{c}\mathrm{CHCl}_{3} \\
\mathrm{EtOH} \\
\mathrm{H}_{2} \mathrm{O}\end{array}$ & +++ \\
\hline \multirow[t]{2}{*}{ carbohydrates } & $\begin{array}{l}\mathrm{CHCl}_{3} \\
\mathrm{EtOH}\end{array}$ & \\
\hline & $\mathrm{H}_{2} \mathrm{O}$ & +++ \\
\hline \multirow{3}{*}{ Volatile oils } & $\mathrm{CHCl}_{3}$ & +++ \\
\hline & $\mathrm{EtOH}$ & \\
\hline & $\mathrm{H}_{2} \mathrm{O}$ & \\
\hline
\end{tabular}

+ Faint, ++ clear, +++ very clear, ++++ highly intense

Various medicinal plants have been used to treat urolithiasis. ${ }^{27,30-33} \mathrm{PA}$ has been used traditionally for its diuretic property and curing kidney other kidney ailments in Algeria. ${ }^{7,34}$ However, very few detailed studies have been done to evaluate its potential along with toxicity studies. A detailed study was performed to evaluate the renal protective and antiurolithiasic efficacy of Paronychia argentea (PA) was evaluated using two extracts, namely aqueous extract (PAA) and butanolic extract $(\mathrm{PAB})$. Aerial parts of this plant was used to prepare both the extracts and evaluate the effect on reduction in calculi aggregation in Wistar rats in which oxalocalciclithiasis was induced by an intraperitoneal injection of sodium oxalate $(\mathrm{NaOx}) .{ }^{35}$ Both the extracts were administered orally for 28 days at various doses. Various parameters such as changes in body weight, liver function test, kidney function test including serum creatinine levels, uric acid, urea, various ions such as $\mathrm{K}^{+}, \mathrm{Ca}^{2+}, \mathrm{Mg}^{2+}$, $\mathrm{Na}^{+}$along with cytosolic enzyme alanine aminotransferase which is usually present in liver and enzyme aspartate aminotransferase which is present in mitochondria of tissues such as heart and kidney were measured post-treatment. Nephrotoxicites were induced in this study by administration of intraperitoneal injection of sodium oxalate which were indicated by elevated levels of blood urea and serum creatinine. It was observed that in contradiction to PAA treated group, groups treated with two doses of PAB showed attenuation in the levels of serum creatinine and blood urea significantly indicating the nephroprotective effect of PAB. Elevated levels of these enzymes are considered as indicator of hepatotoxicity. ${ }^{36}$ It was observed that group treated with PAA had elevated levels of ALT (27\%) and PAL (31-51\%) in serum indicating that PAA is ineffective against toxicity induced by oxalate and did not show hepatoprotection. Overall data in the study suggested that $\mathrm{PAB}$ when administered to rats in which lithiasis was induced by sodium oxalate, reduced and prevented the urinary stones growth, which supported the traditional usage of PA as an antiurolithiatic agent. ${ }^{37,38}$ Mechanism which leads to different activities of two extracts need to be explored which will further prove the antiurolithiatic property of PA extracts.

\section{Protection against Ulcerative Colitis}

Ulcerative colitis affects colon and rectum and is classified as inflammatory bowel disease (IBD) which occurs recurrently and is chronic when relapsed in intestine ${ }^{39}$ Clinical symptoms include diarrhea, stool with blood, pain in abdomen and loss in body weight. ${ }^{40}$ Two most common drugs for treatment of colitis are mesalazine and sulfasalazine. ${ }^{41}$ These drugs are associated with unwanted effects on male fertility along with adverse effect of sulfasalazine including vomiting, hypospermia, hepatitis, pneumonitis, hemolytic anemia and chronic nephrosis andencephalitis. ${ }^{42,43}$ It has been observed that sometimes treatment with sulfasalazine exacerbates colitis which results in diarrhea, abdominal cramps and uneasiness. ${ }^{44}$ These side effects can be overcome by medicinal plant based therapeutics which could have less or no adverse side effects. It is well established fact that oxidative stress contributes majorly to tissue injury and fibrosis which are characteristic features of IBD. Recently a research group has performed in vivo assays to evaluate the effect of PA methanolic extract (PAM) against acetic acidinduced ulcerative colitis in mice. ${ }^{45,46}$ The study was based on the fact that during ulcerative colitis, increased levels of superoxide and nitric oxide lead to peroxynitrite formation which causes oxidation of lipids, proteins and DNA, ${ }^{47}$ reducing these parameters to normal levels by treatment with PA could be a treatment strategy for controlling colitis. It was observed that acetic acid-treated mice groups developed rapidly severe colitis with characteristic symptoms including bloody diarrhea, reduced mobility and food intake, poor coat quality and dramatic body weight loss. Administration of PAM prevented the reduction of body weight. It was further observed that PAM reduced the disease activity index (DAI) significantly, which is a parameter evaluated by severity of weight loss, bleeding from rectum and consistency of stool. Acetic acid had induced severe macroscopic edematous inflammation in the colon and caused colonic shortening and decrease of its wet weight in the colitis control group. It was observed that these changes were improved post treatment with 100, 200 and $500 \mathrm{mg} / \mathrm{kg}$ of PAM. Erythrocyte 
sedimentation rate (ESR) count which is being used as a marker for inflammatory diseases ${ }^{48}$ was found to be reduced to normal levels posttreatment with PAM. Serum C-reactive protein levels, another marker for inflammation was also found to be reduced in treated group when compared with colitis group. As mentioned above, free radicals and reactive oxygen species were reported in ulcerative colitis ${ }^{49}$ along with lipid peroxidation. Malondialdehyde (MDA) is the product of lipid peroxidation, ${ }^{50}$ it was observed that group of mice treated with PAM showed reduced levels of MDA when compared with colitis control group. Data suggested that efficacy of PA against ulcerative colitis was mediated by anti-lipid peroxidation and free radical scavenging ability. Along with above parameters, reduced glutathione (GSH) levels in the colonic tissue of colitis mice was found. Post-treatment with PAM, significant increase in GSH levels was observed when compared with UC control groups. This data further adds that anti-inflammatory effect of PA could be due to its ability to release glutathione..$^{51,52}$

\section{Protection from the oxidative stress}

It has been well proven that pesticide chemicals can lead to oxidative stress through generation of free radicals and it can also alter the antioxidant levels of the enzymes showing free radical scavenging activity. Chlorpyrifos (CE) is one such pesticide used in farms (Figure 3). Its toxicity is mediated by inhibiting acetyl cholinesterase (AChE) along with other mechanisms. This chemical has got ability to modify endogenous antioxidants like SOD, GPX and GSH which may cause oxidative stress in tissues ${ }^{53}$ and can significantly reduce the activities of glutathione (GSH), catalase (CAT) and glutathione- $\mathrm{S}$-transferase (GST).$^{54}$ Many plant extracts have proven anti-oxidant activity which boosts immune response and many studies have shown that flavonoids have antioxidants property. ${ }^{55} \mathrm{PA}$ has a high flavonoid content, this indicates its antioxidant property. Zama et al. have elucidated the role of PA in protection from the oxidative stress caused by CE. ${ }^{7}$ Pregnant albino Wistar rats were used for the study and these were orally fed with pesticide and PA extract. Plasma and tissue malondialdehyde (MDA), GSH and erythrocyte superoxide dismutase (SOD) activities were calculated. MDA levels were estimated in plasma and different organs (liver, kidney, brain, placenta and in the fetuses and their livers) as an indicator of lipid peroxidation (LPO). Effect of CE and butanolic plant extract $(\mathrm{PAB})$ on fetus was observed. Groups treated with $\mathrm{CE}$ showed significant increase in lipid peroxidation levels pesticide which was attenuated by the plant extract (PAB). Also, CE caused a significant decrease in antioxidant enzyme activity and this effect was partially reversed in groups treated with the PAB. The decrease in LPO levels and the increase in GSH and SOD enzyme activities post treatment with $\mathrm{PAB}$ validated its antioxidantproperty. ${ }^{7}$

\section{Anti-bacterial efficacy}

Bacterial community both gram positive and gram negative are the major causative agent for various human infections. ${ }^{56}$ Resistance is developing to available antimicrobials limiting the options for treatment. The prevalence of multi-drug resistance of bacterial strains necessitates new classes of anti-bacterials which can overcome resistance..$^{57,58} \mathrm{PA}$ has been tested for its antimicrobial potential, since plant extracts and molecules derived from them can be a safe alternative. Antimicrobial potential of aqueous and ethanolic extract of Paronychia argentea Lam. (Caryophyllaceae) was studied against six Gram negative bacteria and one Gram positive bacterium. It was observed that ethanol extract of PA exhibited the highest antimicrobial potential against most of the tested bacteria except for Klebsiella pneumoniae and Escherichia coli. ${ }^{59}$ Another most common bacterial infection is by Helicobacter pylori which has been proven to be the major factor in gastric cancer, chronic active gastritis, duodenal ulcer, gastric ulcer and gastric lymphoma. ${ }^{60-63}$ The available treatment regimen for $H$. pylori includes the combination of antibiotics along with agents which can suppress acid formation.
With the prevalence of drug resistance along with side effects and cost of the available treatment, search for new drugs with reduced side effects is the need. ${ }^{64-67}$ A study conducted using PA extract has shown that PA has a moderate efficacy against $H$. pylori.$^{66}$ Another study has shown the efficacy of crude saponins extracted from the aerial parts of PA for the antioxidant, antimicrobial and synergistic effects with antibiotics. The results of minimum inhibitory concentration showed that saponins-rich extract of PA was found to effective against the many Candida strains and Gram-positive bacteria. Moreover, it was found that the combination of saponins rich extract and classical antibiotics exhibited synergistic role against resistant bacteria and Candida. ${ }^{67}$

\section{Alpha amylase inhibitory activitv of Paronychia argentea}

Various medicinal plants are in use in traditional medicines for their hypoglycemic efficacy ${ }^{68}$ Hypoglycemic activity of many such plants has been proven in vivo using animal models. ${ }^{69-72}$ The mechanism for hypoglycaemic potential of many traditional plants has not yet been explored. The hypoglycaemic effect of the plant extracts could be due to decreased absorption of ingested sugars. This could be possible by inhibition of enzymes which degrade complex carbohydrates. One such enzyme Alpha amylase has been evaluated as a prospective target for controlling diabetes since long. ${ }^{73}$ First alpha glucosidase (alpha amylase as well) clinically used was acarbose which was obtained long screening program for glucosidase inhibitors and was significantly efficient in controlling blood glucose. However, it was also associated with side effects such as flatulence. ${ }^{74}$ Moreover, it has been well established that alpha amylase inhibitors have better efficacy than alpha glucosidase inhibitors, since they do not lead to the accumulation of maltose and oligosacharides in the gut. ${ }^{75}$ Based on these facts a study was conducted in Jordan to identify new alpha amylase inhibitors and there mechanism of action for the hypoglycemic efficacy. It was found that PA dried crude extract exhibited significant (more than 80\%) alpha amylase inhibitory activity. This data supported the hypoglycaemic activity of PA mediated by inhibition of alpha amylase activity which was later on contradicted by in vivo and in vitro studies as explained in next section. The activity of PA was attributed to high flavonoid components in it. ${ }^{76,77}$

\section{Hypoglycemic activity of PA}

PA has been reported to have high content of the flavonoids isorhamnetin, quercetin and luteolin. ${ }^{6}$ Various flavonoids aglycons and glycosides have been explored for their hypoglycemic activity. ${ }^{78-84}$ A study was designed to evaluate the effect of PA on the levels of blood sugar, when crude extract was administered intranasal in the rabbits. This mode of drug administration assures rapid the rapid absorption of the drug and quick beginning of the therapeutic action. It was observed that $10 \%$ aqueous extract of PA along with Pluronic F127 (as drug delivery systems) $)^{85,86}$ at a concentration of $5 \%(\mathrm{w} / \mathrm{w})$ did not show any decrease in blood sugar levels. The data suggests that this study need to be further carried out using repeated administration of the extracts, since PA is still widely used in Jordan for hypoglycemic efficacy. ${ }^{87}$ Another study was conducted using inbred male Fisher rats in which diabetes was induced bystreptozocin. ${ }^{88}$ It was observed that PA has no hypoglycemic effect onstreptozocine-induced diabetic or normal rats. This data which is totally different from the traditional medicinal use of PA as hypoglycemic agent emphasises the need for comprehensive scientific evaluation of chemical, pharmacological and biological properties of medicinal plants used locally as nearly half of the population still depend on medicines from plant sources ${ }^{14,89,90}$ The Pharmacological effects of Paronychia argentea were shown in Table 3. The detailed research on activities of less explored medicinal plants of historical practice will not only enhance the available knowledge but also ascertain efficacy and safety. 
Table 3: Pharmacological effects of PA.

\begin{tabular}{|c|c|c|}
\hline Extract tested of Paronychia argentea & In vitro/invivo & Activity \\
\hline $\begin{array}{c}\text { Aqueous extract (PAA) and butanolic } \\
\text { extract (PAB) }\end{array}$ & In vivo in Wistar rats & $\begin{array}{c}\text { Nephroprotective } \\
\text { (PAB when administered to rats with } \mathrm{NaOx}- \\
\text { induced lithiasis, reduced and prevented the } \\
\text { growth of urinary stones) }\end{array}$ \\
\hline PA methanolic extract (PAM) & $\begin{array}{l}\text { In vivo against acetic acid-induced ulcer- } \\
\text { ative colitis in mice }\end{array}$ & $\begin{array}{c}\text { Protective against Ulcerative Colitis } \\
\text { Evident by decreased levels of inflamma- } \\
\text { tory markers and Malondialdehyde (MDA), } \\
\text { product of lipid peroxidation }{ }^{52}\end{array}$ \\
\hline $\begin{array}{l}\text { n -butanolic } \\
\text { extract }\end{array}$ & In vivo in Pregnant albino Wistar rats & $\begin{array}{l}\text { Decreased oxidative stress induced by } \\
\text { Chlorpyrifos (CE) } \\
\text { decrease in LPO levels and theincrease in } \\
\text { GSH and SOD enzyme activities post treat- } \\
\text { ment with PAB validated its antioxidantprop- } \\
\text { erty }^{7}\end{array}$ \\
\hline Aqueous and ethanolic extract of PA & In vitro & $\begin{array}{c}\text { Anti-bacterial efficacy } \\
\text { majority of Candida strains andGram-positive } \\
\text { bacteria, H. Pylori }\end{array}$ \\
\hline Crude extract of PA & In vitro & Alpha amylase inhibitory activitv \\
\hline Aqueous extract of PA & $\begin{array}{l}\text { In vitro and In vivo in streptozocine-in- } \\
\text { duced diabetic rats }\end{array}$ & $\begin{array}{c}\text { Hypoglycemic activity of PA } \\
\text { In contrary to traditional usage, no hypogly- } \\
\text { cemic efficacy was observed }\end{array}$ \\
\hline
\end{tabular}

\section{CONCLUSION}

This review was focussed on the morphology, habitat, photochemistry, traditional medicinal usage and pharmacological evaluation of Paronychia argentea. Available literature showing various bioactivities of PA has strengthened its medicinal value. However, few studies have also given contradictory data when compared with traditional usage of the plant. As in the case of alpha-amylase inhibitory efficacy of PA, it was observed that PA inhibits alpha-amylase activity but later on it was proven that PA does not have a hypoglycemic effect. This emphasises the need for proper investigation of the mechanism of action, toxicity evaluation and clinical studies of this plant. Further detailed studies of the structure of compounds obtained from the extract of PA could lead to synthesis of new therapeutic molecules which could serve as safe and better alternative.

\section{ACKNOWLEDGEMENT}

Nil.

\section{CONFLICT OF INTERESTS}

None.

\section{REFERENCES}

1. Lamarck, J. B., Paronychia argentea Lam. Flore Françoise: 1779; Vol. 3: 230.

2. Abusaief, H. M. A., Dakhil, A.H., The floristic composition of rocky habitat of ALMansora in Al- JabalAl-Akhdar-Libya. NY Sci J. 2013, 6(5), 34-45.

3. Julian, L. S., A composition of bee fauna in two Northern California coastal dune systems. Master of Science in Natural Resources: Biology, Faculty of Humboldt State University. 2012.

4. Alhamad, M. N., Ecological and species diversity of arid Mediterranean grazing land vegetation. J. Arid Environ 2006 66, 698-715.

5. Benítez, G., González-Tejero, M.R., Molero-Mesa, J., Pharmaceutical ethnobotany in the western part of Granda province (southern Spain): Ethnopharmacological synthesis. J Ethnopharmacol 2010, 129, 87-105.

6. Rizk, A. M., The Phytochemistry of the flora of Qatar. In: U. Qatar (Ed.), University of Qatar, Qatar 1986, 22.

7. Zama, D., Meraihi, Z., Tebibel, S., Benayssa, W., Benayache, F., Benayache, S. Vlietinck, A., Chloropyrifos-induced oxidative stress and tissue damage in the liver, kidney, brain and fetus in pregnant rats: the protective role of the butanolic extract of Paronychia argentea L. . Indian J. Pharmacol. 2007, 39, 145-150.

8. Novais, H. M., Santos, I., Mendes, S., Pinto-Gomes, C., Studies on pharmaceutical ethnobotany in Arrabida Natural Park (Portugal). J. Ethnopharmacol. 2004, 93, 183-195.
9. Carmona, M. D., Llorach, R., Obon, C., Rivera, D., "Zahraa", a Unan multicomponent herbal tea widely consumed in Syria: components of drug mixtures and alleged medicinal properties. J Ethnopharmacol 2005, 102, 344 350.

10. Al-Bakri, A. G.; Afifi, F. U., Evaluation of antimicrobial activity of selected plant extracts by rapid XTT colorimetry and bacterial enumeration. J Microbio Methods 2007, 68, (1), 19-25.

11. Dafni, A.; Yaniv, Z.; Palevitch, D., Ethnobotanical survey of medicinal plants in northern Israel. J Ethnopharmacol 1984, 10, (3), 295-310.

12. Gonzalez-Tejero, M. R.; Molero-Mesa, J.; Casares-Porcel, M.; Martinez Lirola, M. J., New contributions to the ethnopharmacology of Spain. J Ethnopharmacol 1995, 45, (3), 157-65

13. Ferreira, A.: Proenca, C.: Serralheiro, M. L.:Araujo, M. E., The in vitro screening for acetylcholinesterase inhibition and antioxidant activity of medicinal plants from Portugal. J Ethnopharmacol 2006, 108, (1), 31-7.

14. Al-Khalil, S. M., A survey of plants used in Jordanian traditional medicine. International Journal of Pharmacogenomics 1995, 33, 317-323.

15. Lev, E.; Amar, Z., Ethnopharmacological survey of traditional drugs sold in the Kingdom of Jordan. J Ethnopharmacol 2002, 82, (2-3), 131-45.

16. Yaniv, Z.; Dafni, A.; Friedman, J.; Palevitch, D., Plants used for the treatment of diabetes in Israel. J Ethnopharmacol 1987, 19, (2), 145-51.

17. Siciliano, T.; Leo, M. D.; Bader, A.; Tommasi, N. D.; Vrieling, K.; Braca, A.; Morelli, I., Pyrrolizidine alkaloids from Anchusa strigosa and their antifeedant activity. Phytochemistry 2005, 66, (13), 1593-600.

18. Muti, H., Olimat, S., HPLC Method of Analysis for Determination and Standardization of Luteolin and Vanillic acid in Dry Extract of Paronychia argentea Lam. OJCHEG 2018, 34, 2721-2727.

19. Hseu, Y. C.; Chang, W. H.; Chen, C. S.; Liao, J. W.; Huang, C. J.; Lu, F. J.; Chia, Y. C.; Hsu, H. K.; Wu, J. J.; Yang, H. L., Antioxidant activities of Toona Sinensis leaves extracts using different antioxidant models. Food Chem Toxicol 2008, 46, (1), 105-14

20. Suja, K. P., Jayalekshmy, A., Arumughan, C., Antioxidant activity of sesame cake extract. Food Chem. (2005), 91, 213-219.

21. Chan, E. W. C., Lim, Y.Y., Wong, S.K., Lim, K.K., Tan, S.P., Lianto, F.S., Yong, M.C., Effects of different drying methods on the antioxidant properties of leaves and tea of ginger species. Food Chem. 2009, 113 166-175.

22. Sait, S.; Hamri-Zeghichi, S.; Boulekbache-Makhlouf, L.; Madani, K.; Rigou, P. Brighenti, V.; Pio Prencipe, F.; Benvenuti, S.; Pellati, F., HPLC-UV/DAD and ESI$\mathrm{MS}(\mathrm{n})$ analysis of flavonoids and antioxidant activity of an Algerian medicinal plant: Paronychia argentea Lam. J Pharm Biomed Anal 2015, 111, 231-40.

23. Braca, A., Bader, A., Sicilianoa, T., De, N.; Tommasic, Secondary metabolites from Paronychia argentea. Magn. Reson. Chem. 2008, 46, 88-93.

24. Smith, C. L., Guay, D.R.P., Di Piero, J.T., Talbert, R.L., Hyes, P.E., Yee, G.C., Matzke, G.R., Posey, L.M., Nephrolithiasis: Pharmacotherapy and Pathophysiology Approach. 2nd ed.; Elsevier: New York, 1992.

25. Perien, E., Perien, E., Composition and structure of urinary stones. Am. J. Med. $1968,45,654-672$ 
26. Khan, S. R.; Finlayson, B.; Hackett, R. L., Experimental calcium oxalate nephrolithiasis in the rat. Role of the renal papilla. Am J Pathol 1982, 107, (1), 59-69.

27. Laroubi, A.; Touhami, M.; Farouk, L.; Zrara, I.; Aboufatima, R.; Benharref, A.; Chait, A., Prophylaxis effect of Trigonella foenum graecum $L$. seeds on renal stone formation in rats. Phytother Res 2007, 21, (10), 921-5

28. Kishimoto, T.; Yamamoto, K.; Sugimoto, T.; Yoshihara, H.; Maekawa, M. Side effects of extracorporeal shock-wave exposure in patients treated by extracorporeal shock-wave lithotripsy for upper urinary tract stone. Eur Urol 1986, 12, (5), 308-13

29. Selvam, R.; Kalaiselvi, P.; Govindaraj, A.; Bala Murugan, V.; Sathish Kumar, A. S., Effect of $A$. lanata leaf extract and Vediuppu chunnam on the urinary risk factors of calcium oxalate urolithiasis during experimental hyperoxaluria. Pharmacol Res 2001, 43, (1), 89-93.

30. Grases, F.; Ramis, M.; Costa-Bauza, A.; March, J. G., Effect of Herniaria hirsuta and Agropyron repens on calcium oxalate urolithiasis risk in rats. J Ethnopharmacol 1995, 45, (3), 211-4

31. McHarg, T.; Rodgers, A.; Charlton, K., Influence of cranberry juice on the urinary risk factors for calcium oxalate kidney stone formation. BJU Int 2003, 92, (7), 765-8.

32. Atmani, F.; Slimani, Y.; Mimouni, M.; Aziz, M.; Hacht, B.; Ziyyat, A., Effect of aqueous extract from Herniaria hirsuta L. on experimentally nephrolithiasic rats. J Ethnopharmacol 2004, 95, (1), 87-93.

33. RamyaPydi, Nephroprotective Medicinal Plants - A review. International Journal of Universal Pharmacy and Life Sciences. 2011, 1, 266.

34. Beloued, A., Plantes médicinales d'Algérie. OPU, Alger,: 1998.

35. Hodgkinsons, A., Oxalic Acid in Biology and Medicine. Academic Press, London: 1977.

36. Al-Mamary, M.; Al-Habori, M.; Al-Aghbari, A. M.; Baker, M. M., Investigation into the toxicological effects of Catha edulis leaves: a short term study in animals. Phytother Res 2002, 16, (2), 127-32.

37. Bouanania, S., Henchiric, C., Migianu-Griffonib, E., Aoufa, N., Lecouveyb, M., Pharmacological and toxicological effects of Paronychia argentea in experimental calcium oxalate nephrolithiasis in rats. J Ethnopharmacol 2010 129, 38-45.

38. Rajagopal, P. L., Premaletha, K., Kiron, S.S., Sreejith, K.R., A Review on Nephroprotective Herbs and Herbal Formulations. International Journal of Chemical and Pharmaceutical Research 2013, 2.

39. Sakthivel, K. M.; Guruvayoorappan, C., Amentoflavone inhibits iNOS, COX-2 expression and modulates cytokine profile, NF-kappaB signal transduction pathways in rats with ulcerative colitis. Int Immunopharmacol 2013, 17, (3), 90716.

40. Liu, L.; Yuan, S.; Sun, Y.; Long, Y.; Li, Y.; Niu, Y.; Li, C.; Gan, H.; Cao, S.; Mei, Q., The possible mechanisms of Fructus Mume pill in the treatment of colitis induced by 2,4,6-trinitrobenzene sulfonic acid in rats. J Ethnopharmacol 2009 , 126, (3), 557-64.

41. Lissner, D.; Siegmund, B., Ulcerative colitis: current and future treatment strategies. Dig Dis 2013, 31, (1), 91-4.

42. Ben-Horin, S.; Kopylov, U.; Chowers, Y., Optimizing anti-TNF treatments in inflammatory bowel disease. Autoimmun Rev 2014, 13, (1), 24-30

43. DeMichele, J.; Rezaizadeh, H.; Goldstein, J. I., Sulfasalazine crystalluria-induced anuric renal failure. Clin Gastroenterol Hepatol 2012, 10, (2), A32.

44. Tremblay, L.; Pineton de Chambrun, G.; De Vroey, B.; Lavogiez, C.; Delaporte, E.; Colombel, J. F.; Cortot, A., Stevens-Johnson syndrome with sulfasalazine treatment: report of two cases. J Crohns Colitis 2011, 5, (5), 457-60.

45. Neurath, M. F.; Fuss, I.; Kelsall, B. L.; Stuber, E.; Strober, W., Antibodies to interleukin 12 abrogate established experimental colitis in mice. J Exp Med 1995, 182, (5), 1281-90.

46. Rachmilewitz, D.; Karmeli, F.; Takabayashi, K.; Hayashi, T.; Leider-Trejo, L.; Lee, J.; Leoni, L. M.; Raz, E., Immunostimulatory DNA ameliorates experimental and spontaneous murine colitis. Gastroenterology 2002, 122, (5), 1428-41.

47. V, V. P.; C, G., Protective effect of marine mangrove Rhizophora apiculata on acetic acid induced experimental colitis by regulating anti-oxidant enzymes, inflammatory mediators and nuclear factor-kappa B subunits. Int Immunopharmacol 2014, 18, (1), 124-34.

48. Boopala-Bhagavan, N., Arunachalam, S., Dhasarathan, P., Kannan, N.D. Evaluation of anti inflammatory activity of Indigofera aspalathoides Vahl in Swiss albino mice. J. Pharm. Res. 2013, 6, 350-354.

49. Bitiren, M.; Karakilcik, A. Z.; Zerin, M.; Ozardali, I.; Selek, S.; Nazligul, Y.; Ozgonul, A.; Musa, D.; Uzunkoy, A., Protective effects of selenium and vitamin E combination on experimental colitis in blood plasma and colon of rats. Biol Trace Elem Res 2010, 136, (1), 87-95.

50. Ohkawa, H., Ohishi, N., Yagi, K., Assay for lipid peroxides in animal tissues by thiobarbituric acid reaction. Anal Biochem. 1979, 95, 351-8.
51. Peran, L.; Camuesco, D.; Comalada, M.; Nieto, A.; Concha, A.; Adrio, J. L.; Olivares, M.; Xaus, J.; Zarzuelo, A.; Galvez, J., Lactobacillus fermentum, a probiotic capable to release glutathione, prevents colonic inflammation in the TNBS model of rat colitis. Int J Colorectal Dis 2006, 21, (8), 737-46.

52. Adjadj, M., Baghiani, A., Boumerfeg, S., Noureddine, C., Khennouf, S., Arrar L., Mubarak, M.S., Protective Effect of Paronychia argentea L. on Acetic Acid Induced Ulcerative Colitis in Mice by Regulating Antioxidant Parameters and Inflammatory Markers. Der Pharma Chemica 2016, 8(4), 207-218.

53. Bebe, F. N.; Panemangalore, M., Exposure to low doses of endosulfan and chlorpyrifos modifies endogenous antioxidants in tissues of rats. J Environ Sci Health B 2003, 38, (3), 349-63.

54. Goel, A.; Dani, V.; Dhawan, D. K., Protective effects of zinc on lipid peroxidation, antioxidant enzymes and hepatic histoarchitecture in chlorpyrifos-induced toxicity. Chem Biol Interact 2005, 156, (2-3), 131-40.

55. Gao, Z.; Xu, H.; Chen, X.; Chen, H., Antioxidant status and mineral contents in tissues of rutin and baicalin fed rats. Life Sci 2003, 73, (12), 1599-607.

56. Nathan, C., Antibiotics at the crossroads. Nature 2004, 431, (7011), 899-902.

57. Akins, R. L.; Haase, K. K., Gram-positive resistance: pathogens, implications and treatment options: insights from the Society of Infectious Diseases Pharmacists. Pharmacotherapy 2005, 25, (7), 1001-10.

58. Cornaglia, G., Fighting infections due to multidrug-resistant Gram-positive pathogens. Clin Microbiol Infect 2009, 15, (3), 209-11.

59. Shurooq, I., Screening of Selected Medicinal Wild Plant Extracts Antibacterial Effect as Natural Alternatives. Int. J. Indig. Med. Plants 2013, 46, (2).

60. De Francesco, V.; Giorgio, F.; Hassan, C.; Manes, G.; Vannella, L.; Panella, C. lerardi, E.; Zullo, A., Worldwide H. pylori antibiotic resistance: a systematic review. J Gastrointestin Liver Dis 2010, 19, (4), 409-14.

61. Kawai, T.; Fukuzawa, M.; Moriyasu, F; Yamashina, A., [Influence of H. pylor infection on upper gastrointestinal damage]. Nihon Rinsho 2010, 68, (11), 2020-

62. Krueger, S.; Roessner, A.; Kuester, D., Murine models of H. pylori-induced gastritis and gastric adenocarcinoma. Pathol Res Pract 2011, 207, (10), 599-607.

63. Touati, E., When bacteria become mutagenic and carcinogenic: lessons from H. pylori. Mutat Res 2010, 703, (1), 66-70.

64. Alzoubi, K.; Rashdan, A.; Al-Dayyat, A.; Al-Safi, S., Is maintenance acid suppression necessary to reduce the rate of reinfection with Helicobacter pylori? Hepatogastroenterology 2007, 54, (80), 2406-9.

65. Di Mario, F.; Cavallaro, L. G.; Scarpignato, C., 'Rescue' therapies for the management of Helicobacter pylori infection. Dig Dis 2006, 24, (1-2), 113-30.

66. Masadeh, M. M.; Alkofahi, A. S.; Tumah, H. N.; Mhaidat, N. M.; Alzoubi, K. H., Antibacterial activity of some medicinal plants grown in Jordan. Pak J Pharm Sci 2013, 26, (2), 267-70.

67. Brahim , M. A. S., Fadli, M., Markouk, M., Hassani, L., Larhsini, M., Synergistic Antimicrobial and Antioxidant Activity of Saponins-Rich Extracts from Paronychia argentea and Spergularia marginata. European J Med Plants 2015 7(4), 193-204.

68. Abu Irmailah, B., Afifi, F., Treatment with medicinal plants in Jordan. Dirasat Med Biol Sci. 2000, 2753-74.

69. Ajabnoor, M., Tilmisany, A. J.; , Effect of Trigonella foenum graecum on blood glucose levels in normal and alloxan diabetic mice. J Ethnopharmacol. 1988, $22,45-49$

70. Gharaibeh, M., Elyan H., Salhab, A. J., Hypoglycemic effects of Teucrium polium. J. Ethnopharmacol. 1988, 24, 93-99.

71. Ribes, G.; Sauvaire, Y.; Da Costa, C.; Baccou, J. C.; Loubatieres-Mariani, M. M., Antidiabetic effects of subfractions from fenugreek seeds in diabetic dogs. Proc Soc Exp Biol Med 1986, 182, (2), 159-66.

72. Sharma, R. D.; Raghuram, T. C.; Rao, N. S., Effect of fenugreek seeds on blood glucose and serum lipids in type I diabetes. Eur J Clin Nutr 1990, 44, (4), 301-6.

73. Jung, B., Matzke, M., Stoltefus, J., , Chemistry and structure activity relationships of glucosidase inhibitors. In: Handbook of experimental pharmacology: Oral antidiabetics.. Berlin: Springer-Verlag: 1996; Vol. 41

74. Lebovitz, H. E., Postprandial hyperglycaemic state: importance and consequences. Diabetes Res Clin Pract 1998, 40 Suppl, S27-8.

75. Kim, J. S.; Kwon, C. S.; Son, K. H., Inhibition of alpha-glucosidase and amylase by luteolin, a flavonoid. Biosci Biotechnol Biochem 2000, 64, (11), 2458-61.

76. Hansawasdi, C.; Kawabata, J.; Kasai, T., Alpha-amylase inhibitors from roselle (Hibiscus sabdariffa Linn.) tea. Biosci Biotechnol Biochem 2000, 64, (5), 1041-3.

77. Rawand, S., Abu, S., Imad, I., Hamdan, F., Afifi, U., Alpha amylase inhibitory activitv of some plant extracts with hyporrlvcemic activitv. Sci. Pharm. 2004 72, 25-33.

78. Zarzuelo, A.; Jimenez, I.; Gamez, M. J.; Utrilla, P.; Fernadez, I.; Torres, M. I.; Osuna, I., Effects of luteolin 5-O-beta-rutinoside in streptozotocin-induced diabetic rats. Life Sci 1996, 58, (25), 2311-6. 
79. Koenig, G. M., Wright, A.D., Keller, W.J., Judd, R.L., Bates, S., Day, C., Hypoglycemic activity of an HMG-containing flavonoid glucoside, chamaemeloside from Chamaemelum nobile. Planta Medica 1998, 64, 612-614.

80. Ong, K. C.; Khoo, H. E., Effects of myricetin on glycemia and glycogen metabolism in diabetic rats. Life Sci 2000, 67, (14), 1695-705.

81. Borradaile, N. M.; de Dreu, L. E.; Huff, M. W., Inhibition of net HepG2 cell apolipoprotein $\mathrm{B}$ secretion by the citrus flavonoid naringenin involves activation of phosphatidylinositol 3-kinase, independent of insulin receptor substrate-1 phosphorylation. Diabetes 2003, 52, (10), 2554-61.

82. Jung, U. J.; Lee, M. K.; Jeong, K. S.; Choi, M. S., The hypoglycemic effects of hesperidin and naringin are partly mediated by hepatic glucose-regulating enzymes in C57BL/KsJ-db/db mice. J Nutr 2004, 134, (10), 2499-503.

83. Kim, H. Y.; Moon, B. H.; Lee, H. J.; Choi, D. H., Flavonol glycosides from the leaves of Eucommia ulmoides $\mathrm{O}$. with glycation inhibitory activity. J Ethnopharmacol 2004, 93, (2-3), 227-30.

84. Pinent, M.; Blay, M.; Blade, M. C.; Salvado, M. J.; Arola, L.; Ardevol, A., Grape seed-derived procyanidins have an antihyperglycemic effect in streptozotocininduced diabetic rats and insulinomimetic activity in insulin-sensitive cell lines. Endocrinology 2004, 145, (11), 4985-90.
85. Oh, K. T.; Bronich, T. K.; Kabanov, A. V., Micellar formulations for drug delivery based on mixtures of hydrophobic and hydrophilic Pluronic block copolymers. $J$ Control Release 2004, 94, (2-3), 411-22.

86. Saettone, M. F.; Alderigi, C.; Giannaccini, B.; Anselmi, C.; Rossetti, M. G.; Scotton, M.: Cerini, R., Substantivity of sunscreens-preparation and evaluation of some quaternary ammonium benzophenone derivatives. Int J Cosmet Sci 1988, 10, (3), 99-109.

87. Afifi, F. U., Khalidi B. A., Khalil, E., Studies on the in vivo hypoglycemic activities of two medicinal plants used in the treatment of diabetes in Jordanian traditional medicine following intranasal administration. J Ethnopharmacol 2005, 100, 314-318.

88. Junod, A.; Lambert, A. E.; Stauffacher, W.; Renold, A. E., Diabetogenic action of streptozotocin: relationship of dose to metabolic response. J Clin Invest 1969, 48, (11), 2129-39.

89. Fawzi, M. K., Wild flowers of Jordan. Centre for Jordanian Studies, Irbid: 1998

90. Oran, S. A., Al-Eisawi, D.M., Check list of medicinal plants in Jordan. Dirasat, Med. Biol. Sci. 1998, 25, 84-112.

\section{GRAPHICAL ABSTRACT}

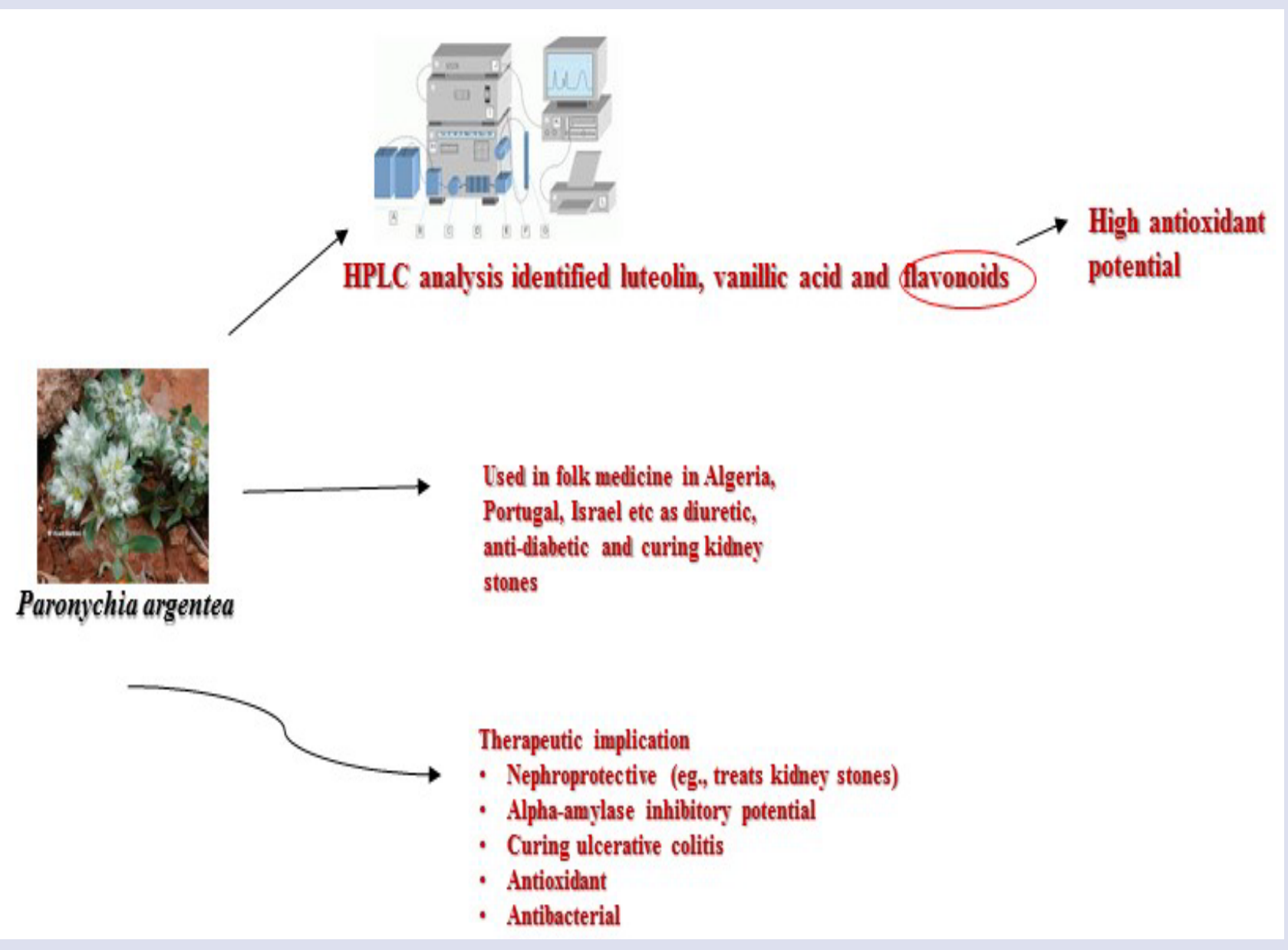

Cite this article: Veeraraghavan VP, Hussain S, Balakrishna JP, Mohan SK. Paronychia Argentea: A Critical Comprehensive Review on its Diverse Medicinal Potential and Future as Therapeutics. Pharmacogn J. 2020;12(5):1172-9. 